\title{
LEE METCALF NATIONAL WILDLIFE REFUGE PRELIMINARY AMPHIBIAN AND REPTILE INVESTIGATIONS: 1996
}

\author{
A Report to: \\ U.S. Fish and Wildlife Service \\ Lee Metcalf National Wildlife Refuge \\ P.O. Box 257 \\ Stevensville, MT 59870
}

Submitted by

Paul Hendricks

May 1997
Montana Natural Heritage Program 1515 East Sixth Avenue
P.O. Box 201800
Helena, MT 59620-1800




\section{(c) 1997 Montana Natural Heritage Program}

This document should be cited as follows:

H endricks, P. 1997. Lee $M$ etcalf $\mathrm{N}$ ational $\mathrm{W}$ ildlife Refuge preliminary amphibian and reptile investigations: 1996. Montana $\mathrm{N}$ atural Heritage Program. Helena, MT. 27 pp. 


\begin{abstract}
During summer 1996, field surveys of resident amphibians and reptiles were initiated on Lee Metcalf National Wildlife Refuge, Ravalli County, Montana. Studies were focused on three projects: 1) compilation of available specimen and sight records for the area, 2) preliminary assessment of Bullfrog (Rana catesbeiana) distribution and status, 3 ) preliminary assessment of Painted Turtle (Chrysemys picta) distribution and status.

Five species of amphibian and seven species of reptile have been reported from the Bitterroot Valley between Victor and Florence. Long-toed Salamander (Ambystoma macrodactylum), Tailed Frog (Ascaphus truei), Western Toad (Bufo boreus), Bullfrog, Spotted Frog (Rana pretiosa), Painted Turtle, Western Skink (Eumeces skiltonianus), Rubber Boa (Charina bottae), Gopher Snake (Pituophis catenifer), Western Terrestrial Garter Snake (Thamnophis elegans), and Common Garter Snake (Thamnophis sirtalis) were recorded in the Bitterroot River floodplain, which includes Lee Metcalf National Wildlife Refuge. In recent years few amphibians other than Bullfrogs have been reported from the refuge.

Bullfrogs are abundant on the refuge; adults and transformed juveniles were noted in 10 water bodies, and probably are present in several others. On 29 August, 449 frogs were counted in North Slough during a census of the entire shore and adjacent water; the slough probably contained well over 2000 individuals. Sweeping with dip nets nearshore resulted in capture of only one group of 5 tadpoles, suggesting that transformation of many tadpoles had already occurred. Many Bullfrog tadpoles were seen that same day, however, at the Florence Bridge Fishing Access site, about $5 \mathrm{~km}$ north of the refuge. Juvenile Bullfrogs with tails still present were seen in ponds near Barn Slough on 16 September. Available information indicates that transformation occurs over several weeks.

Painted Turtles are found throughout the refuge (noted in nine water bodies in 1996), although they were not seen in some ponds with gravel bottoms (e.g., Pond 2). No estimate of numbers was made for any water body, but 28 adults were observed basking at one time in the Viewing Pond on 13 September. A trapping effort was conducted in September; 3 adult males were captured (all in or near the Viewing Pond and Barn Slough), measured, and marked. Trapping probably occurred too late for maximum effectiveness, but the methodology will work for future efforts. No data on nesting habitat, clutch size, and nest success were gathered.
\end{abstract}




\section{ACKNOWLEDGMENTS}

Special thanks to Pat Gonzales and Sharon Browder (Lee Metcalf National Wildlife Refuge) for encouragement and interest in the project. The amphibian and reptile work at the refuge would not be moving along without their help and enthusiasm. Lori Nordstrom (U.S.F.W.S., Helena) obtained funds for this initial effort. Jim Reichel, Kerwin Werner, Bryce Maxell, and Julie York helped with the field work, and shared ideas for sampling and future efforts. Turtle traps were obtained on loan through Joe Ball (Montana Cooperative Wildlife Research Unit). Cedron Jones generated the distribution maps from records in the Montana Natural Heritage Program database. 


\section{INTRODUCTION}

Many amphibian species in the western United Sates are experiencing dramatic population declines (Blaustein et al. 1994, Phillips 1995). A litany of explanations, including elevated predation rates and introduced exotics, have been proposed, any or all of which could contribute to the downward trends (Corn and Fogelman 1984, Phillips 1990).

Conditions at Lee Metcalf National Wildlife Refuge have caused concerns about the resident native amphibian and reptile populations. First, nest predators (mammals and birds) are numerous on the refuge; coupled with this is the impression that few hatchling Painted Turtles are recruited into the local population. The concern is that predators are destroying most nests and young. Second, there is a large population of exotic Bullfrogs on the refuge and general absence of native amphibians, even though the refuge could support other amphibian species. The impact of Bullfrogs on native species is not known, nor is there any quantitative data available on the size and extent of the Bullfrog population on the refuge.

Preliminary surveys were initiated in 1996 to gather together information on the amphibians and reptiles on the refuge. First, museum and sight records were compiled for the Bitterroot Valley between Victor and Florence; this region includes Lee Metcalf National Wildlife Refuge. Additonal observations of amphibians and reptiles in this area were recorded during field surveys in 1996, and place the refuge in context with what is known about the regional herpetofauna (Hendricks and Reichel 1996). These data were plotted on distribution maps generated from records in the Montana Natural Heritage Program database. Second, a preliminary inventory of Bullfrog presence across the refuge was conducted, and attempts were made to estimate numbers in isolated ponds. Third, a preliminary inventory of Painted Turtle presence across the refuge was conducted concurrent with the Bullfrog inventory; sites suitable for trapping and marking turtles were located and a pilot trapping effort was begun. 


\section{METHODS, RESULTS, AND DISCUSSION}

\section{Amphibian and Reptile Species in the Refuge Area}

Compilation of museum specimen and sight records resulted in 12 amphibian and reptile species documented in the Bitteroot Valley area between Victor and Florence (see distribution maps). Included species were one salamander (Long-toed Salamander), four ìfrogsî (Tailed Frog, Western Toad, Bullfrog, Spotted Frog), one turtle (Painted Turtle), two lizards (Northern Alligator Lizard, Western Skink), and four snakes (Rubber Boa, Gopher Snake, Western Terrestrial Garter Snake, Common Garter Snake). All species but the Northern Alligator Lizard have been reported in or immediately adjacent to the Bitterroot River floodplain, where Lee Metcalf National Wildlife Refuge is located. This suggests that most or all of these species could occur on the refuge, given suitable conditions.

Records of amphibians and reptiles in the Montana Natural Heritage Program database for Lee Metcalf National Wildlife Refuge include far fewer species (Bullfrog, Painted Turtle, Gopher Snake, Western Terrestrial Garter Snake). This discrepency is probably an artifact rather than a real ìhistoricalî absence from the refuge; most sightings probably never get reported or recorded. For example, personnel at the refuge mentioned encounters with Long-toed Salamanders and Spotted Frogs in recent years, but no file of amphibian and reptile observations is maintained (Gonzales pers. comm.). Nevertheless, failure to observe these amphibians on the refuge during 1996, even though Long-toed Salamander and Spotted Frog (as well as Bullfrog, Painted Turtle, Western Terrestrial Garter Snake, and Common Garter Snake) were observed $5 \mathrm{~km}$ north at the Florence Bridge Fishing Access, indicates the possibility of greatly reduced populations on the refuge.

\section{Bullfrogs}

To assess Bullfrog distribution on the refuge, visits were made to most ponds and water bodies at least once during suitable weather. Most visits were made in late August and September, however, which likely influenced impressions of presence and relative abundance.

Bullfrogs were found throughout the refuge, from Pond 13 in the north to Pond 3 in the south (n $=10$ sites). Bullfrogs probably occur in most water bodies of relative permanence, although it is not known in what percentage reproduction occurs. Because adults burrow in mud to hibernate during winter, ponds with gravel bottoms and little mud may not be occupied year-round by this species. Originally, it was planned to sample an entire pond for Bullfrogs, but a suitable site was not located until necessary field help was no longer available. Instead, entire shoreline counts were considered the most likely method to provide an estimate of relative abundance. The entire shoreline of North Slough was walked on 29 August (air temp. $=21^{\circ} \mathrm{C}$, water temp. $=18.5^{\circ} \mathrm{C} ; 11: 40-12: 45$ ). Five persons walked different segments, sweeping the nearshore water for tadpoles and counting the number of adult and juvenile frogs encountered from the shore to about $6 \mathrm{~m}$ offshore. During this survey 449 individual frogs were counted (the majority were small adults and juveniles: $\mathrm{SVL}=7-9 \mathrm{~cm}$ ). Given the volume of the slough and the area actually sampled, the count was estimated to be as much as an order of magnitude low; North Slough population was considered to be at least 2000 individuals. The total Bullfrog population on the refuge must be much larger, but the age/size structure of the population (or any subpopulation) is unknown. 
Only 5 tadpoles $(\mathrm{TL}=5.5-7.0 \mathrm{~cm})$ were collected during nearshore netting in North Slough, indicating most tadpoles had already transformed in this pond. Bullfrog tadpoles were much more abundant in one pond at the Florence Bridge Fishing Access site on the same day, indicating transformation occurred at different times among (and within?) ponds. Transformed juvenile Bullfrogs $(\mathrm{SVL}=6.0 \mathrm{~cm})$ with tails $4 \mathrm{~cm}$ long, and tailess juveniles of the same size, were present in a small pond north of Barn Slough on 16 September (air temp $=15^{\circ} \mathrm{C}$, water temp. $=14^{\circ} \mathrm{C}$ ). Transformation of tadpoles in Missouri takes 11-14 months (Willis et al. 1956), but time between hatching and transformation is not known for Montana populations. Size at transformation in Oregon is 11.5-14.0 $\mathrm{cm}$ TL and typically occurs in August and September (Nussbaum et al. 1983) after tadpoles overwinter.

\section{Painted Turtles}

As with Bullfrogs, visits were made to ponds throughout the refuge to determine the distribution of Painted Turtles. Turtles were found in nine large ponds and were absent from four ponds where Bullfrogs were present. Three of these ponds were very small (<60 m diameter or long) and ephemeral, and the fourth (Pond 3) apparently has a gravel bottom with little accumulated mud. Painted Turtles, like Bullfrogs, need ponds with deep mud bottoms in which to hibernate for the winter. It is not known how much movement occurs between ponds, nor if some ponds are used for brief periods. Number of turtles in any pond is unknown. On 13 September (air temp. $=22^{\circ} \mathrm{C}$ ), 28 Painted Turtles were counted basking at one time in Pond 5. Number of basking turtles at any time is limited by the availability of basking sites (logs, rocks, open banks). Thus, the count for Pond 5 is a minimum estimate of the resident population on that date.

Ten basking traps (Fowle 1996) were set in North Slough and Barn Slough on 9 September. The traps in North Slough were moved to Pond 5 on 13 September. Traps were checked every 2-3 days and were retrieved on 23 September. Trap success was low. Cool and wet weather could have contributed to this, and some traps had brittle netting through which some turtles apparently escaped. More time might have been necessary for turtles to habituate to the presence of the traps, and trapping might be more successful earlier in the summer. All of these factors need to be considered in future trapping efforts.

All captured Painted Turtles $(n=3)$ were adult males. Each was given a unique set of marks (see Appendix) by notching various combinations of marginal scutes with a triangular file (see Cagle 1939 and Fowle 1996 for discussions of marking procedures), weighed, and measured (plastron length and width). Two males were caught in Pond 5 and one in Barn Slough; it is likely that turtles move back and forth between these two water bodies. Weights (g) were 585, 740, and 765. Respective plastron lengths $(\mathrm{cm})$ were 16.2, 16.8, and 17.7; plastron widths $(\mathrm{cm})$ were 10.7, 11.1, and 11.4.

No attempt was made to locate nests and follow their fates. No small juvenile turtles were noted during trapping and surveys, but no systematic pond watches were made, which precludes assuming their absence. These aspects of the life cycle need study to determine if recruitment in the Painted Turtle population at Lee Metcalf National Wildlife Refuge is exceptionally low. Adult survivorship is usually high in Painted Turtles, which are long-lived once they reach adulthood; nest loss 
can be substantial (>50-60\%), and hatchling mortality can also be high (see Gibbons 1968, Tinkle et al. 1981, Snow 1982, Christens and Bider 1987, Zweifel 1989, Lindeman 1991, Iverson and Smith 1993). It is unknown, at this time, if stage-related mortality is unusual on the refuge or typical of many populations. 
LONG-TOED SALAMANDER - AMBYSTOMA MACRODACTYLUM

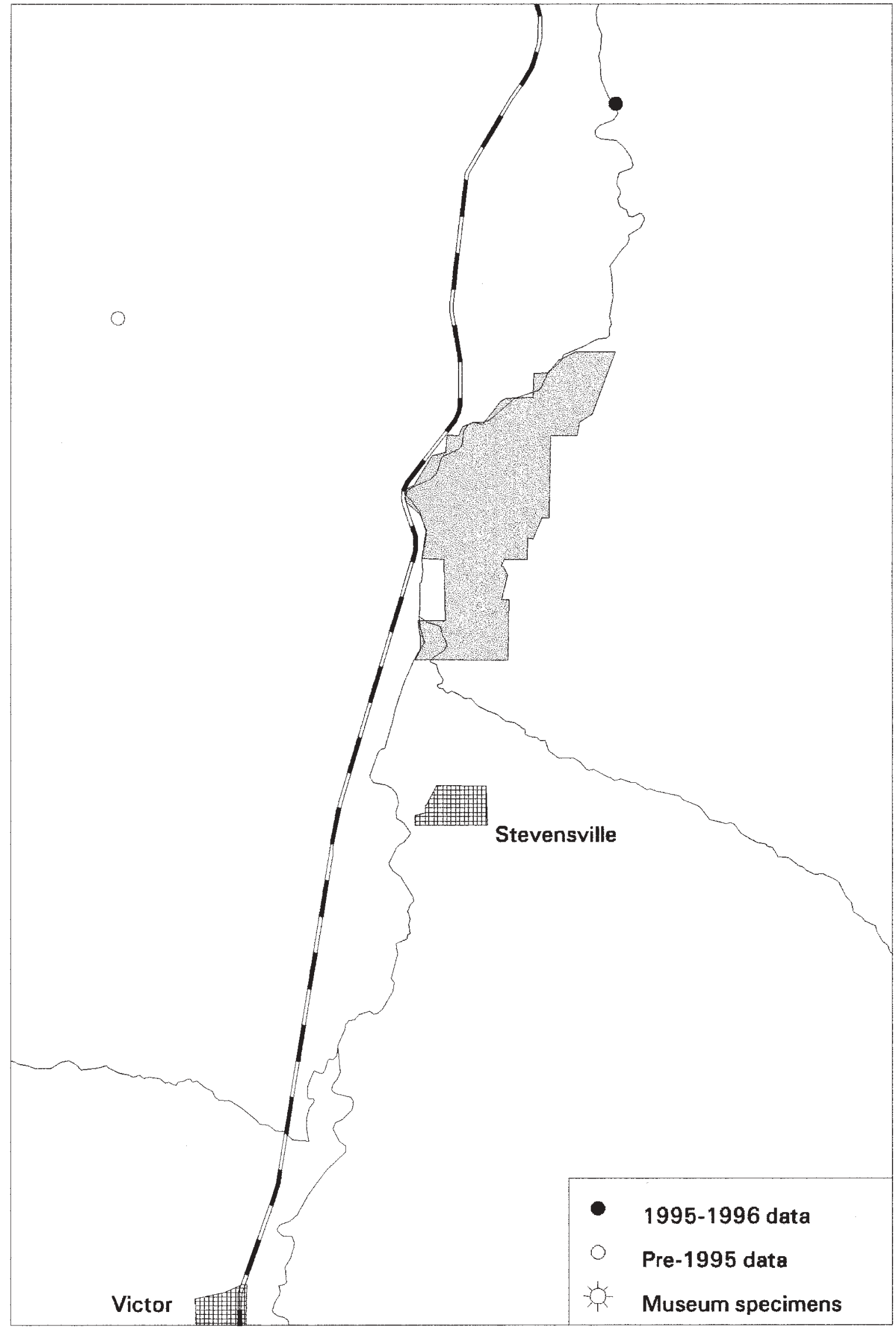

Montana Natural Heritage Program, January 19, 1997 
TAILED FROG - ASCAPHUS TRUEI

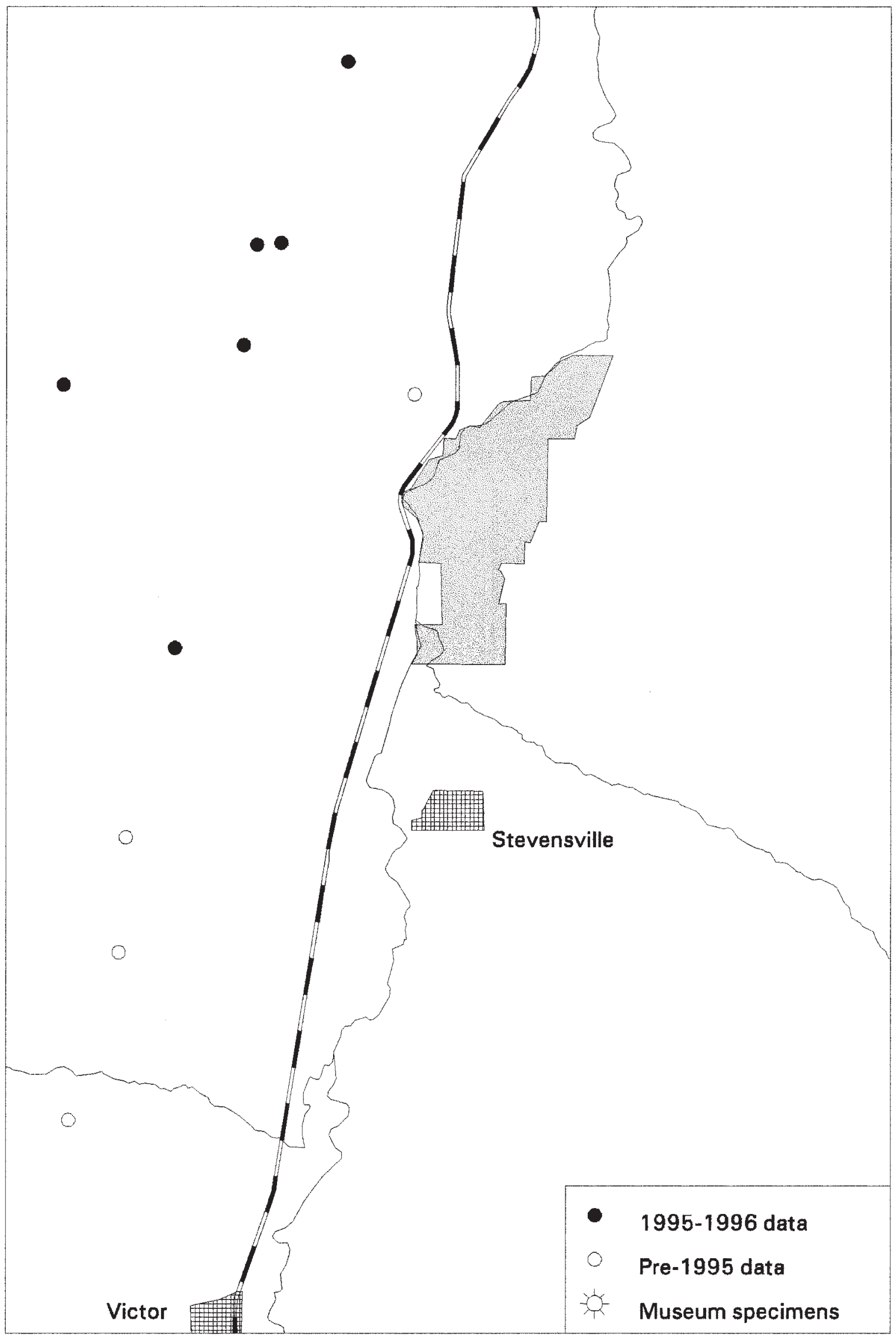

Montana Natural Heritage Program, January 19, 1997 


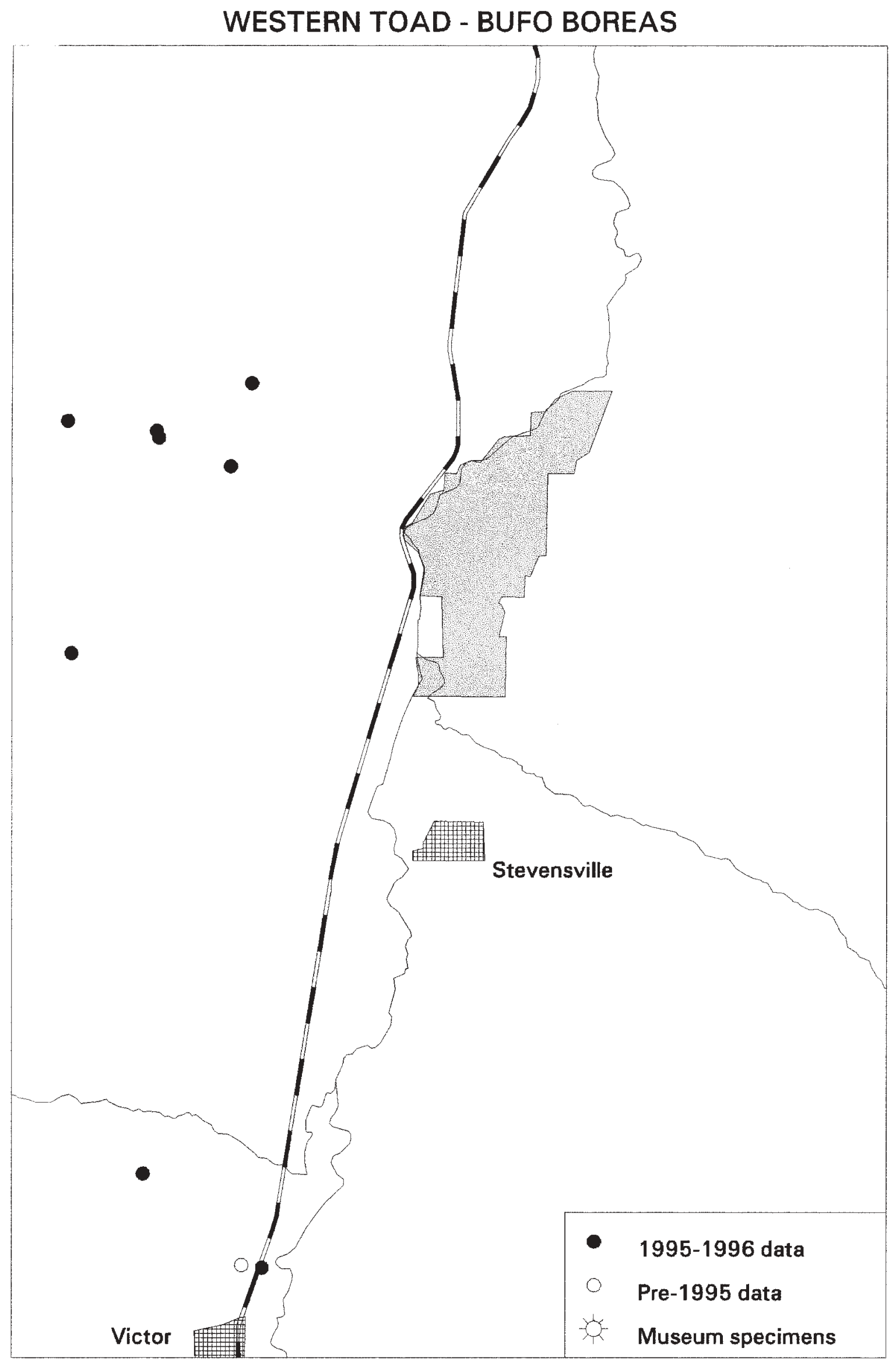

Montana Natural Heritage Program, January 19, 1997 


\section{BULLFROG - RANA CATESBEIANA}

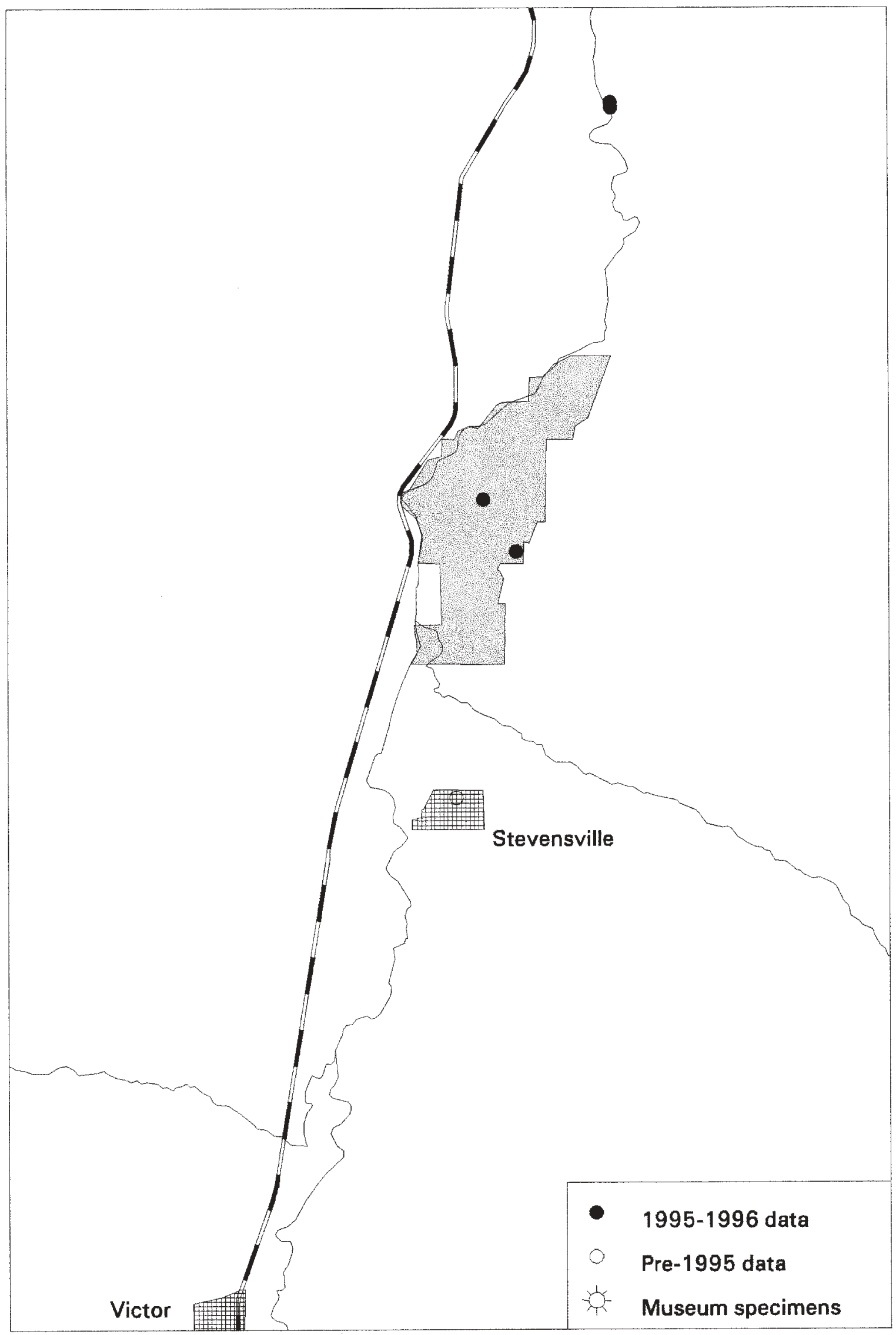

Montana Natural Heritage Program, January 19, 1997 
SPOTTED FROG - RANA PRETIOSA

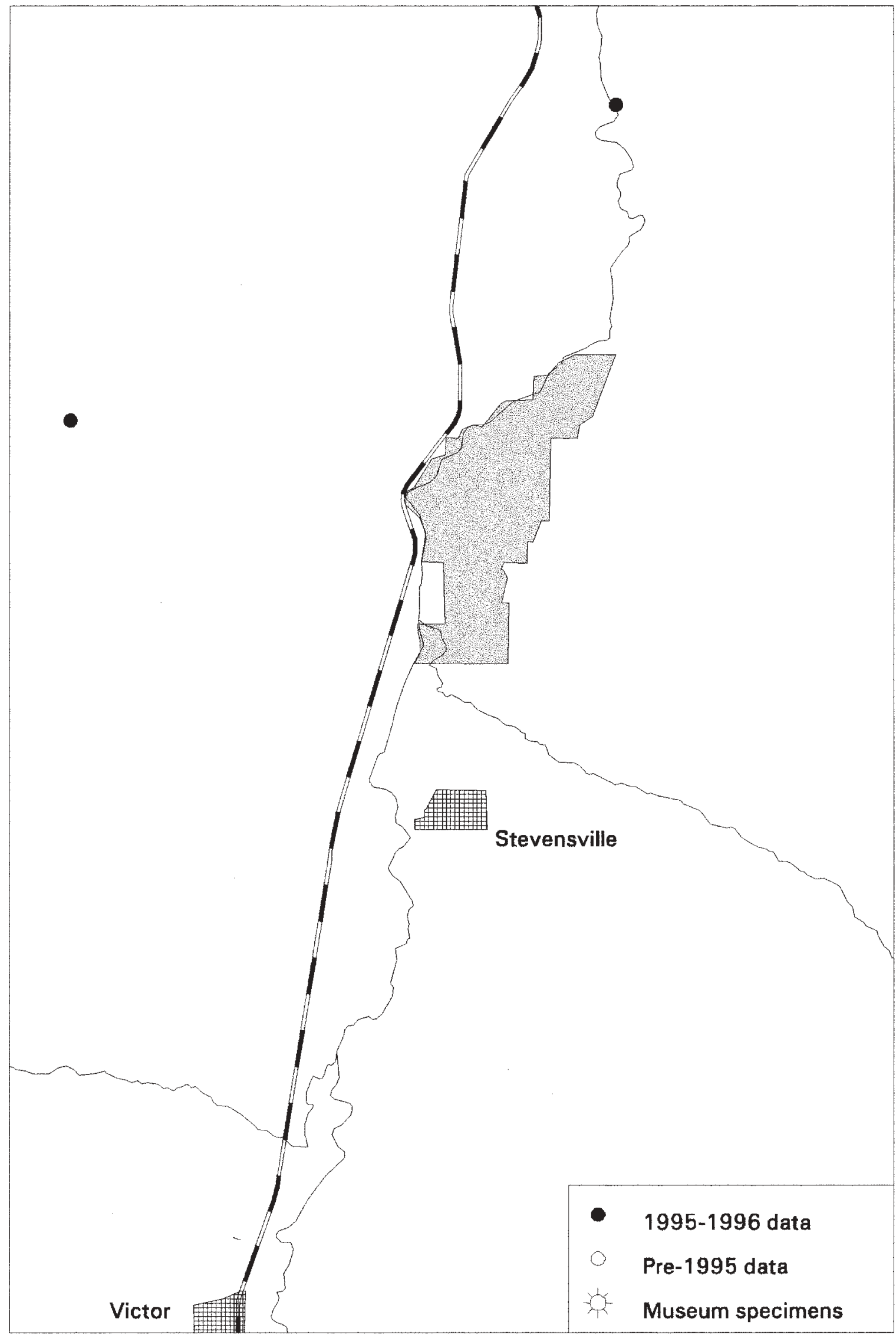

Montana Natural Heritage Program, January 19, 1997 


\section{PAINTED TURTLE - CHRYSEMYS PICTA}

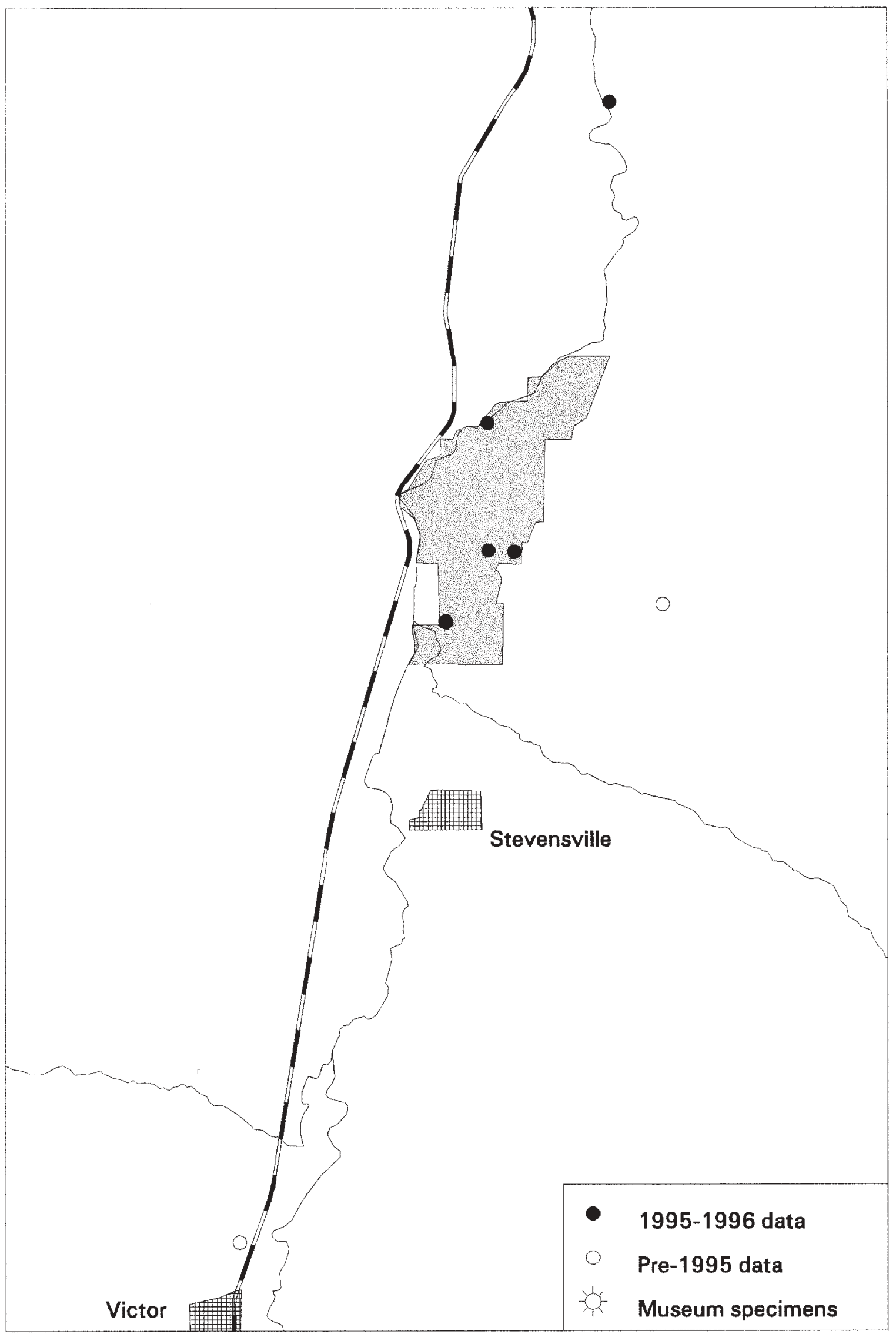

Montana Natural Heritage Program, January 19, 1997 


\section{NORTHERN ALLIGATOR LIZARD - ELGARIA COERULEA}

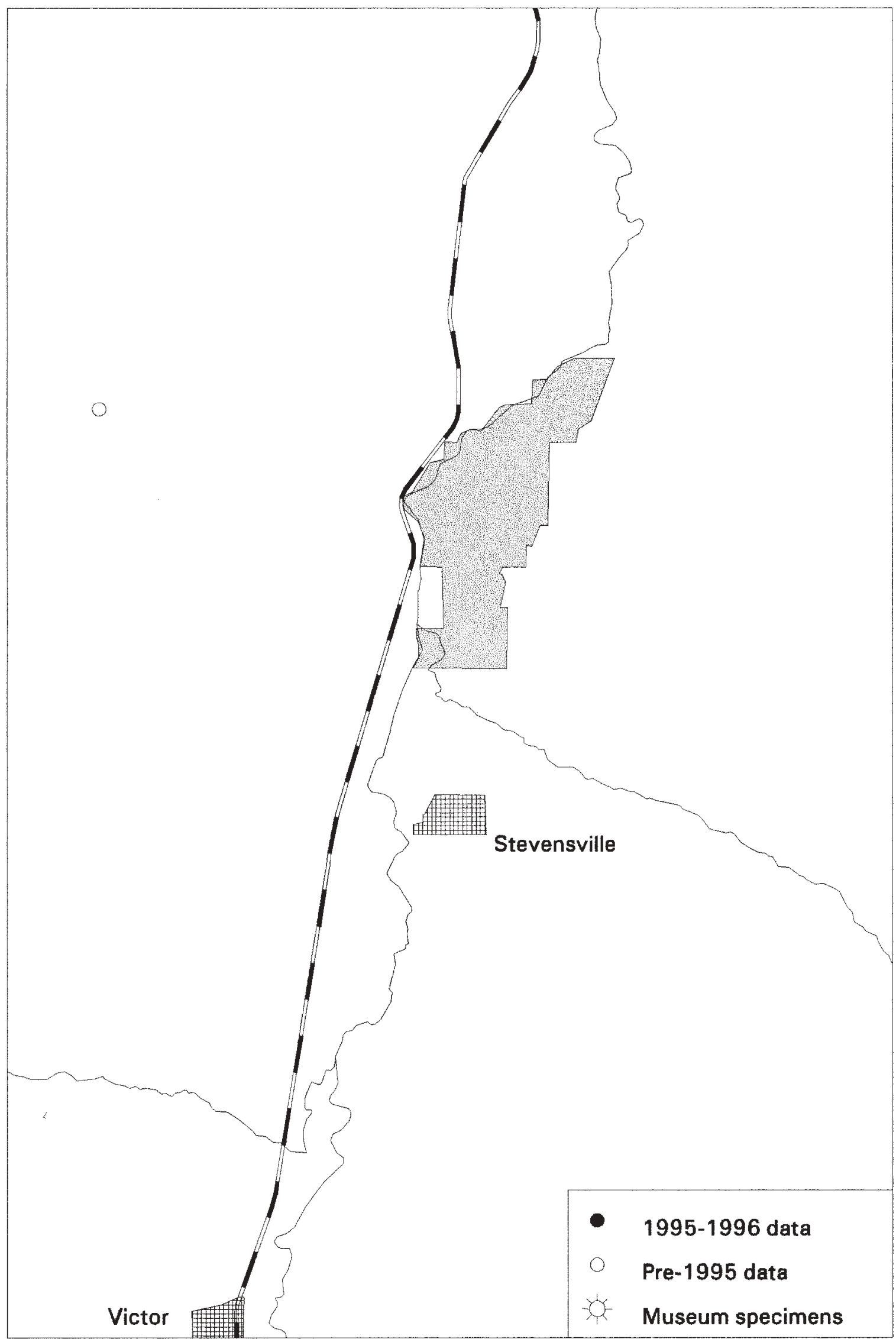

Montana Natural Heritage Program， January 19, 1997 


\section{WESTERN SKINK - EUMECES SKILTONIANUS}

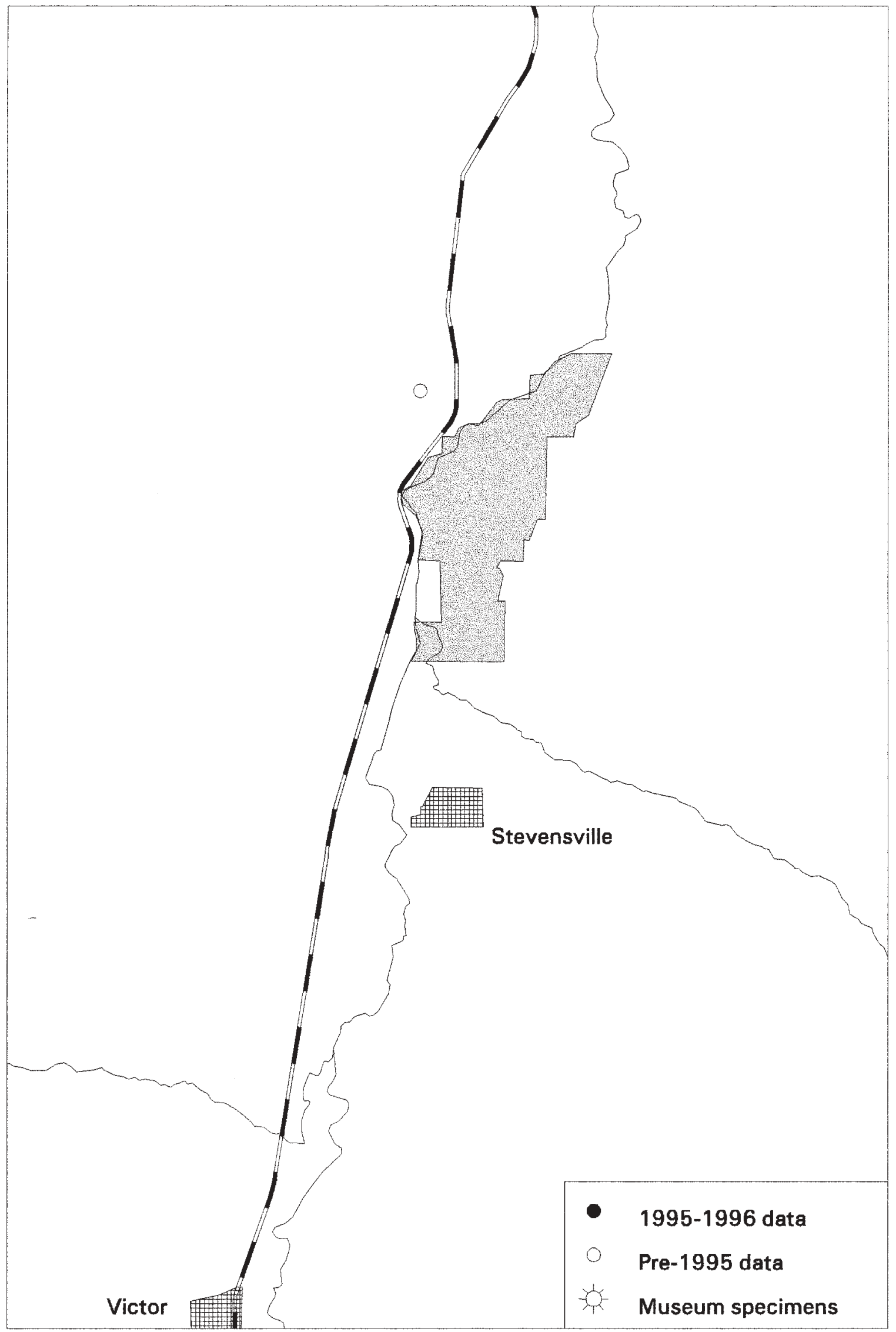

Montana Natural Heritage Program, January 19, 1997 
RUBBER BOA - CHARINA BOTTAE

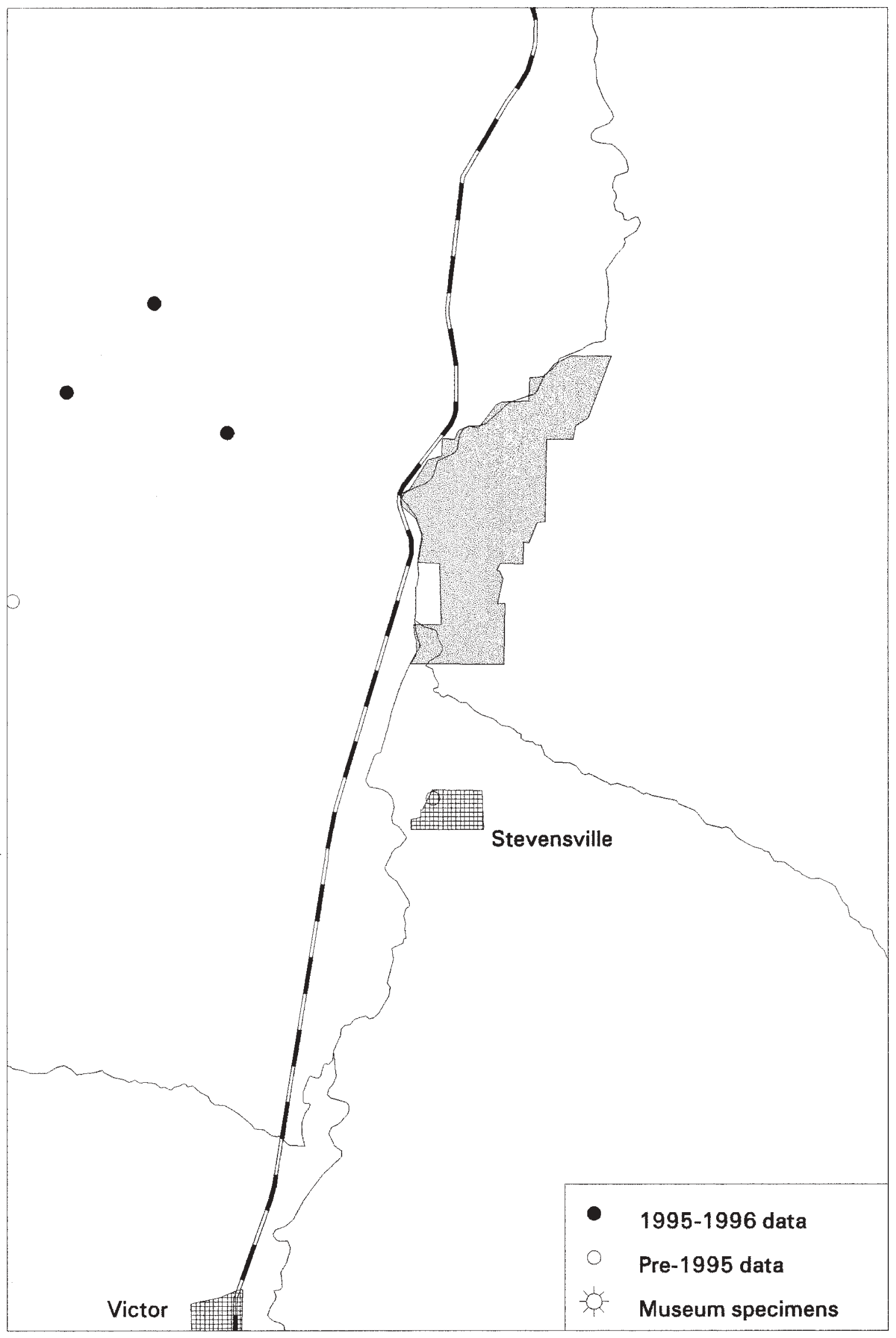

Montana Natural Heritage Program, January 19, 1997 


\section{GOPHER SNAKE OR BULLSNAKE - PITUOPHIS CATENIFER}

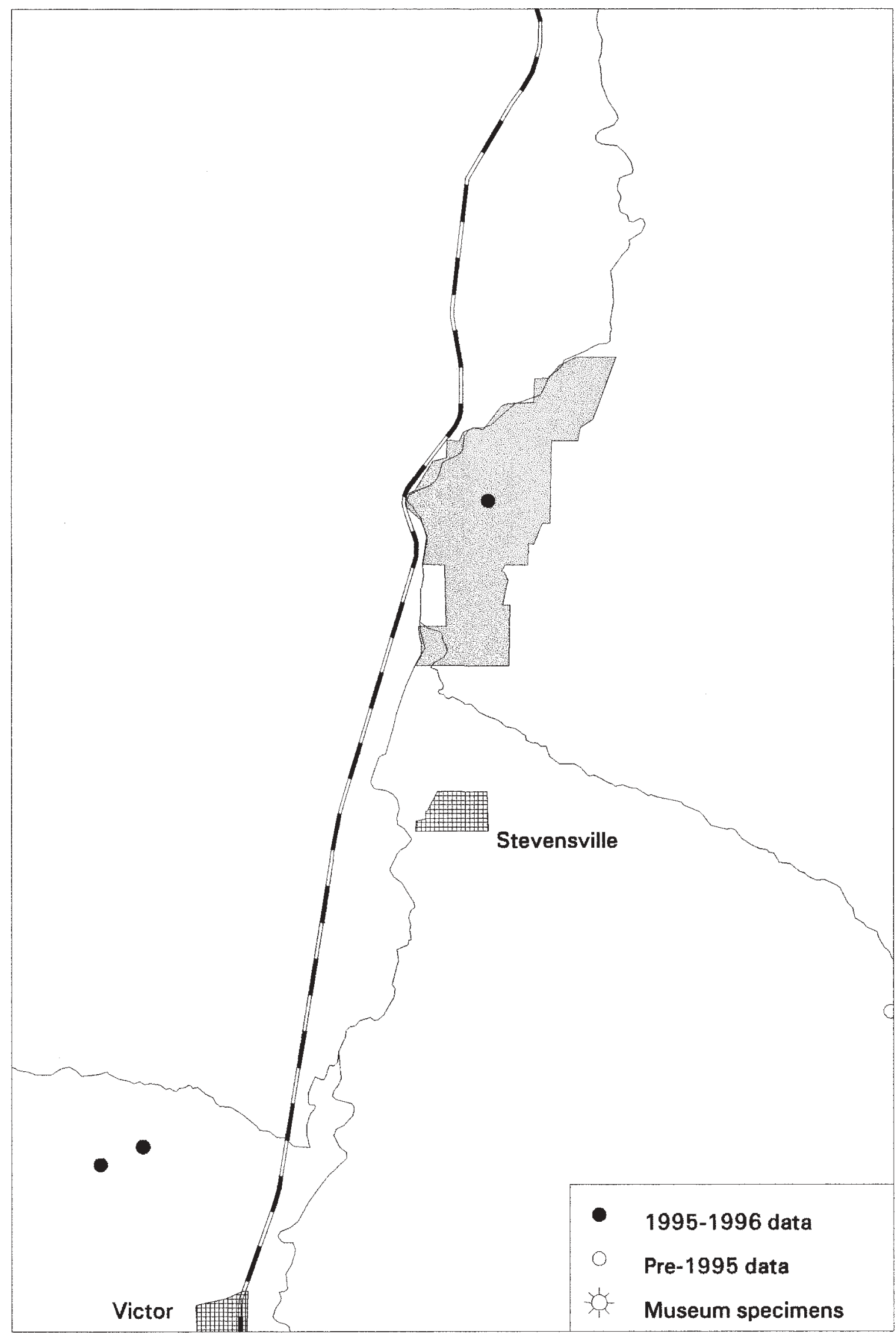

Montana Natural Heritage Program, January 19, 1997 


\section{WESTERN TERRESTRIAL GARTER SNAKE - THAMNOPHIS ELEGANS}

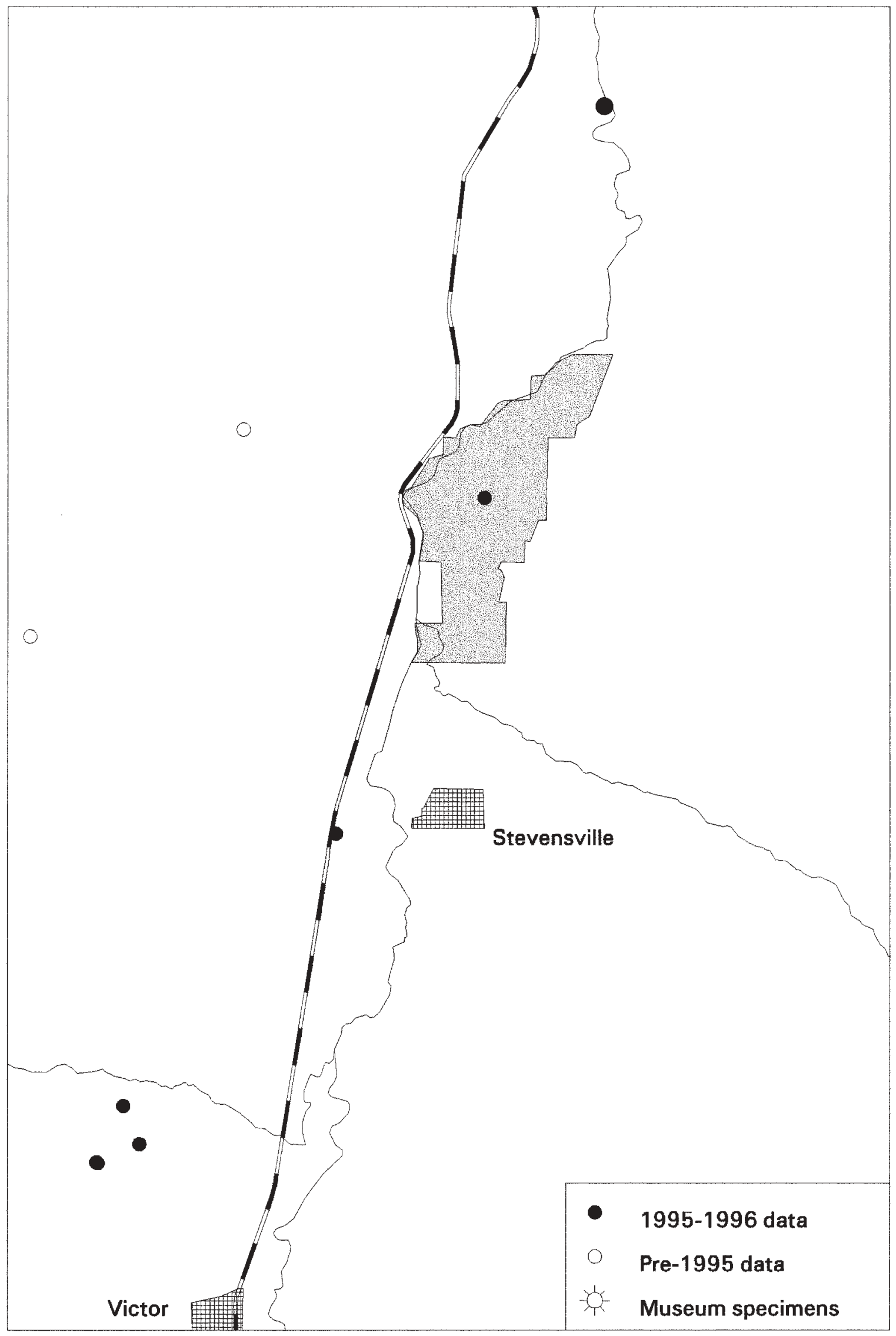

Montana Natural Heritage Program, January 19, 1997 


\section{COMMON GARTER SNAKE - THAMNOPHIS SIRTALIS}

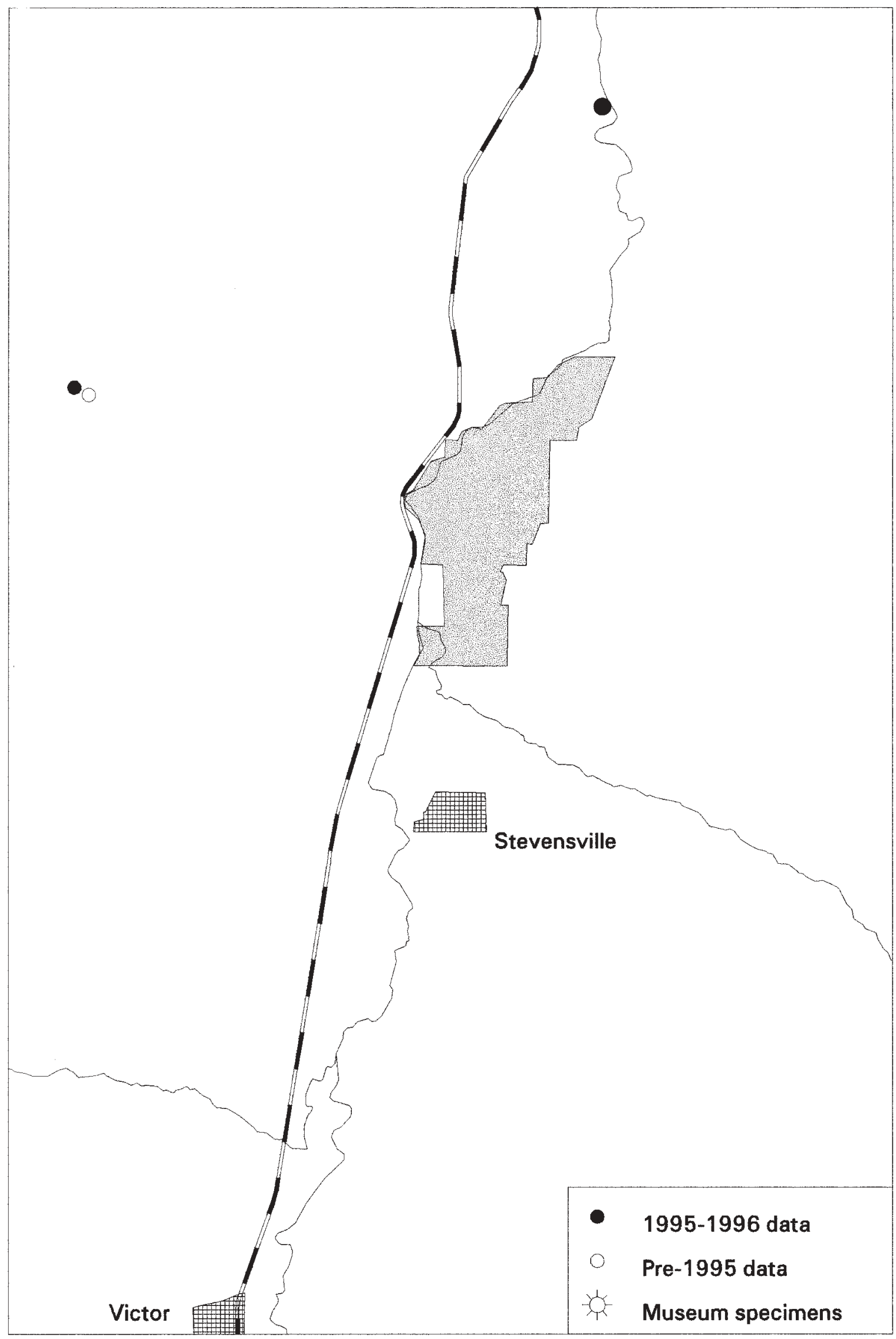

Montana Natural Heritage Program， January 19, 1997 


\section{SUGGESTIONS FOR FUTURE WORK}

1) Develop and maintain a file of all amphibian and reptile observations on the refuge. Design an observation form that can be used by all personnel, and encourage permanent and seasonal staff to become familiar with the species in the area (about a dozen species total). Of interest to the refuge are estimates of numbers of Bullfrogs and Painted Turtles in particular ponds, observations of turtle nests, acts of predation observed on nests and adults, and sightings of amphibians other than Bullfrogs. Spot counts of basking turtles in particular ponds, accompanied by weather conditions, can provide valuable estimates of relative abundance when recorded over several years for the same sites. These kinds of data do not require large blocks of time to obtain, but can be very useful for detecting changes that may be occurring on the refuge.

2) Continue efforts to mark Painted Turtles and gather age (size) distribution data; initial efforts should concentrate on one or two ponds (Pond 5 and Barn Slough). Locate turtle nests and monitor their fates. Determine which predators prey on nests and hatchlings. Refuge personnel indicated that nesting routinely occurs along the railroad tracks. This would be a good place to develop a nest-monitoring program. At some time, with suitable funding, follow movements of radio-marked turtles to determine distances moved and amount of movement between ponds. Radio-marked females could be followed to nest sites, as well.

3) Continue efforts to estimate the size of the Bullfrog population on the refuge; continue shoreline counts of Bullfrogs in North Slough. Determine when mating and egg-laying occur, time of transformation for tadpoles, length of tadpole phase, food habits of adults, and habitat suitability across the refuge (Are all water bodies used by Bullfrogs? Is Bullfrog reproduction successful in ponds occupied by predatory fish?). Almost nothing is known about the biology of Bullfrogs in this region of North America. A study of overwinter survivorship could provide insight about the factors restricting the spread of this species in western Montana. 


\section{LITERATURE CITED}

Blaustein, A. R., D. B. Wake, and W. P. Sousa. 1994. Amphibian declines: judging stability, persistence, and susceptibility of populations to local and global extinctions. Conservation Biology 8:60-71.

Cagle, F. R. 1939. A system of marking turtles for future identification. Copeia 1939:170-173.

Christens, E., and J. R. Bider. 1987. Nesting activity and hatching success of the Painted Turtle (Chrysemys picta marginata) in southwestern Quebec. Herpetologica 43:55-65.

Corn, P. S., and J. C. Fogelman. 1984. Extinction of montane populations of Northern Leopard Frog (Rana pipiens) in Colorado. Journal of Herpetology 18:147-152.

Fowle, S. C. 1996. The Painted Turtle in the Mission Valley of western Montana. Unpublished Masters Thesis. University of Montana, Missoula. $101 \mathrm{pp}$.

Gibbons, J. W. 1968. Population structure and survivorship in the Painted Turtle, Chrysemys picta. Copeia 1968:260-268.

Hendricks, P., and J. D. Reichel. 1996. Amphibian and reptile survey of the Bitterroot National Forest: 1995. Montana Natural Heritage Program. Helena, MT. 95 pp.

Iverson, J. B., and G. R. Smith. 1993. Reproductive ecology of the Painted Turtle (Chrysemys picta) in the Nebraska Sandhills and across its range. Copeia 1993:1-21.

Lindeman, P. V. 1991. Survivorship of overwintering hatchling Painted Turtles, Chrysemys picta, in northern Idaho. Canadian Field-Naturalist 105:263-266.

Nussbaum, R. A., E. D. Brodie, Jr., and R. M. Storm. 1983. Amphibians and reptiles of the Pacific Northwest. University of Idaho Press, Moscow. 332 pp.

Phillips, K. 1990. Where have all the frogs and toads gone? BioScience 40:422-424.

Phillips, K. 1994. Tracking the vanishing frogs. Penguin Books, New York. 244 pp.

Snow, J. E. 1982. Predation on Painted Turtle nests: nest survival as a function of nest edge. Canadian Journal of Zoology 60:3290-3292.

Tinkle, D. W., J. D. Congdon, and P. C. Rosen. 1981. Nesting frequency and success: implications for the demography of Painted Turtles. Ecology 62:1426-1432.

Willis, Y. L., D. L. Moyle, and T. S. Baskett. 1956. Emergence, breeding, hibernation, movements and transformation of the Bullfrog, Rana catesbeiana, in Missouri. Copeia 1956:30-41. 
Zweifel, R. G. 1989. Long-term ecological studies on a population of Painted Turtles, Chrysemys picta, on Long Island, New York. American Museum Novitates Number 2952. 55 pp. 
APPENDIX 1

TURTLE MARKING FORM 


\section{TURTLE MARKING FORM}

DATE:

LOCATION:

TEMPERATURE (AIR):

SEX:

MAX. PLASTRON LENGTH:

COMMENTS:
TEMPERATURE (WATER):

WEIGHT:

MAX. PLASTRON WIDTH:

INDIVIDUAL NUMBER:

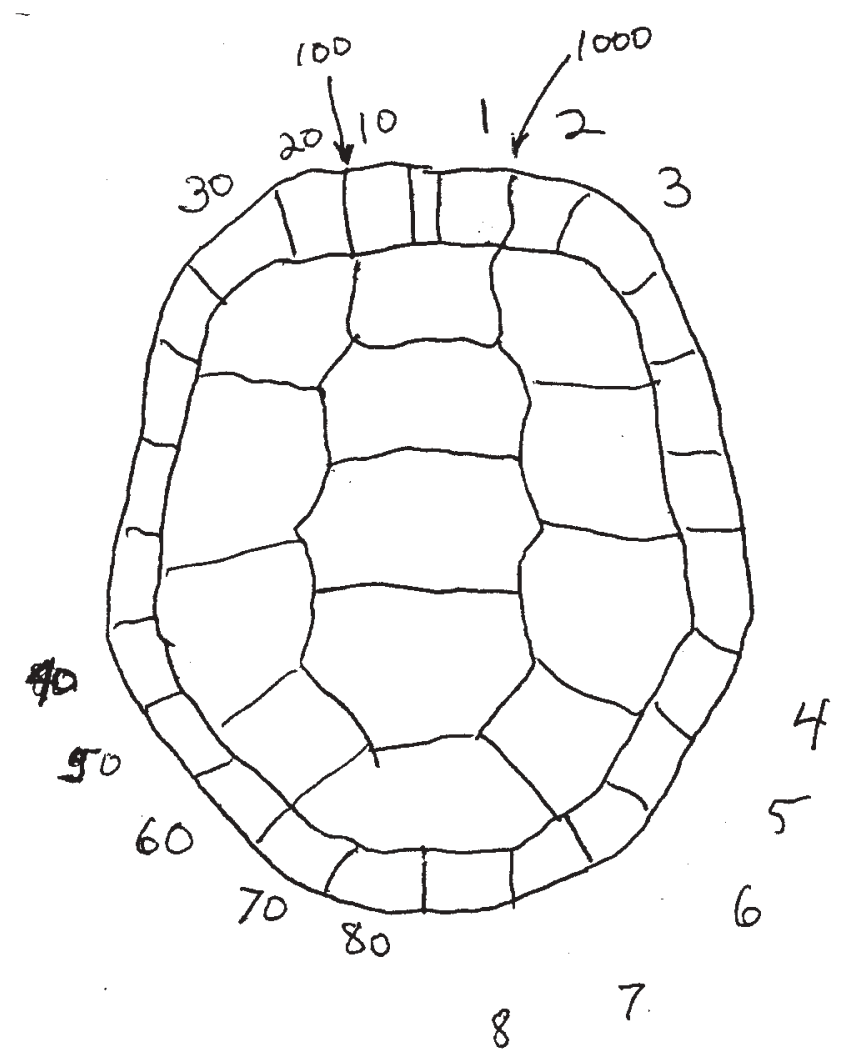


APPENDIX 2

\section{SUMMARY OF AMPHIBIAN AND REPTILE RECORDS}

BETWEEN FLORENCE AND VICTOR 


\section{Multi_Species_Report}

CNAME DATE SURVEY DATÁTYPE BREEDING MUSEUM \# COLLECTOR

COUNTY

LOCATION
TOWNRANGE

\section{COMMENTS}

LONG-TOED SALAMANDER AMBYSTOMA MACRODACTYLUM

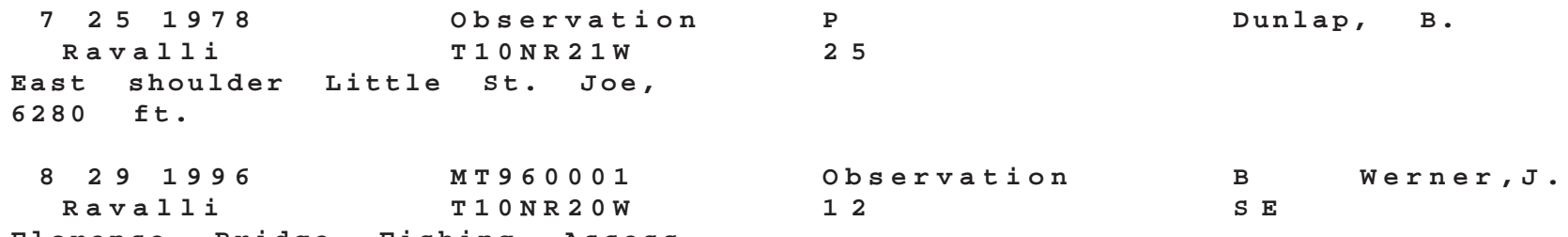

TAILED FROG

Florence Bridge Fishing Acces

\section{ASCAPHUS TRUEI}

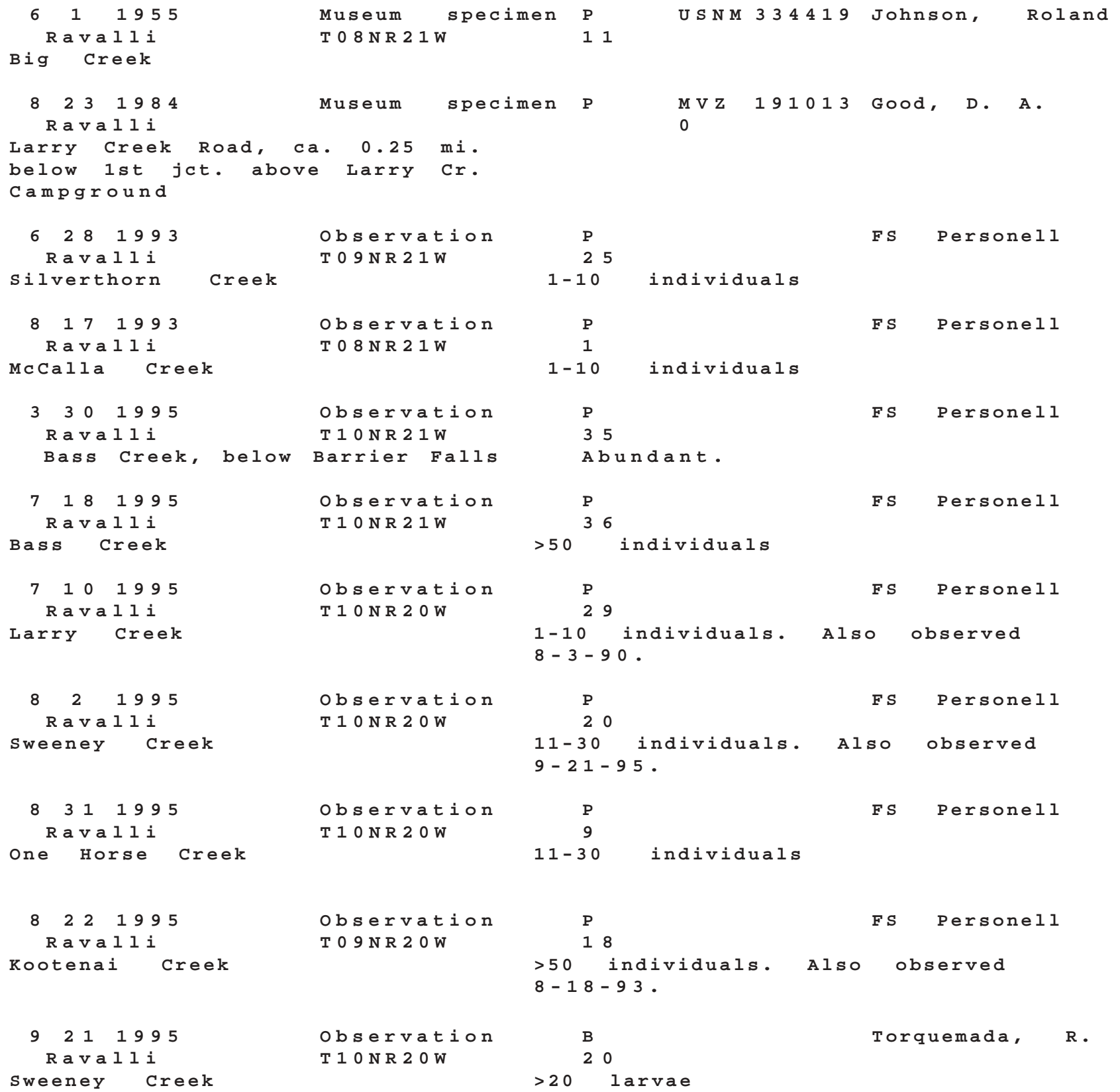


COUNTY LOCATION
TOWNRANGE

\section{COMMENTS}

WESTERN TOAD

BUFO BOREAS

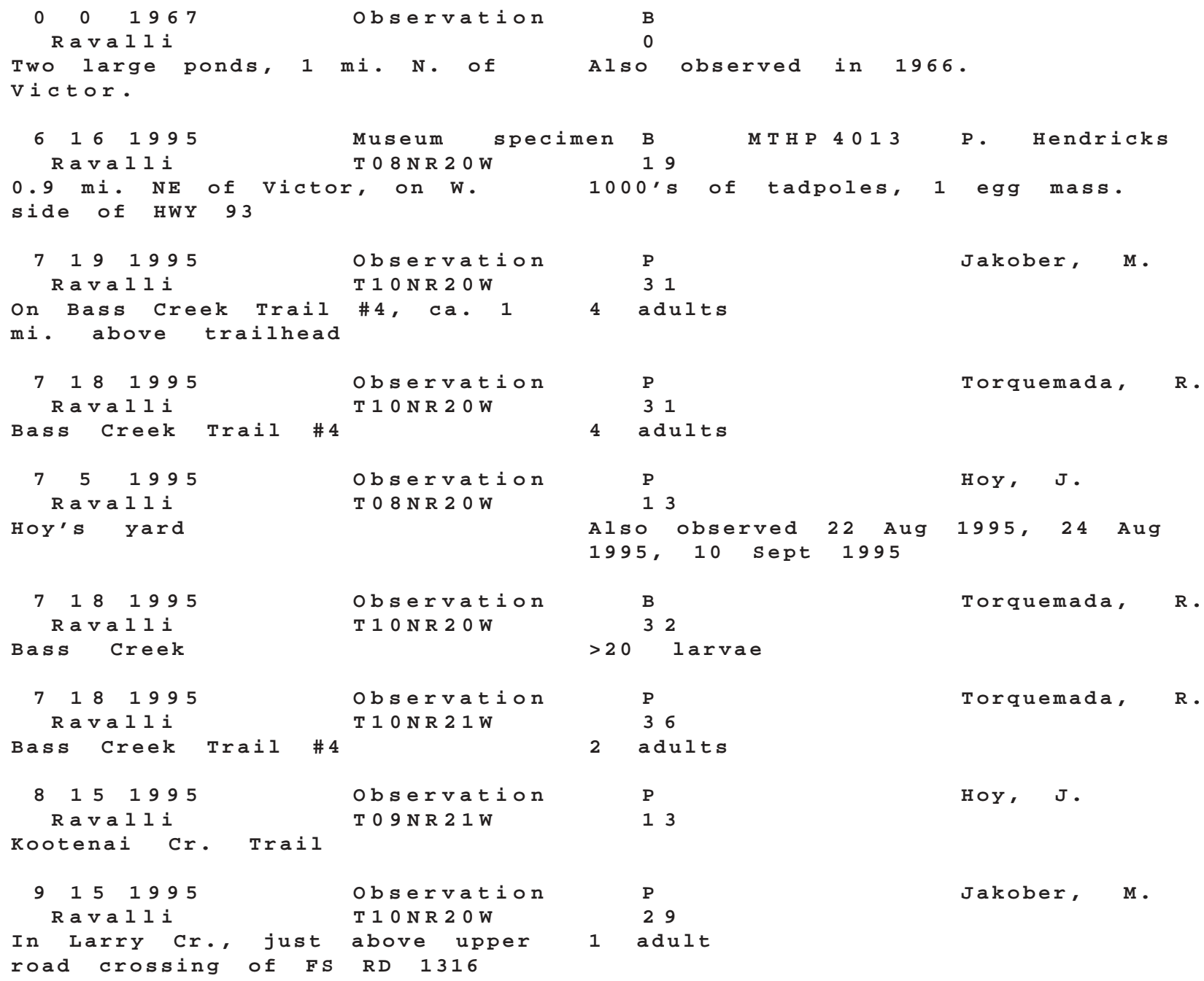

\section{BULLFROG}

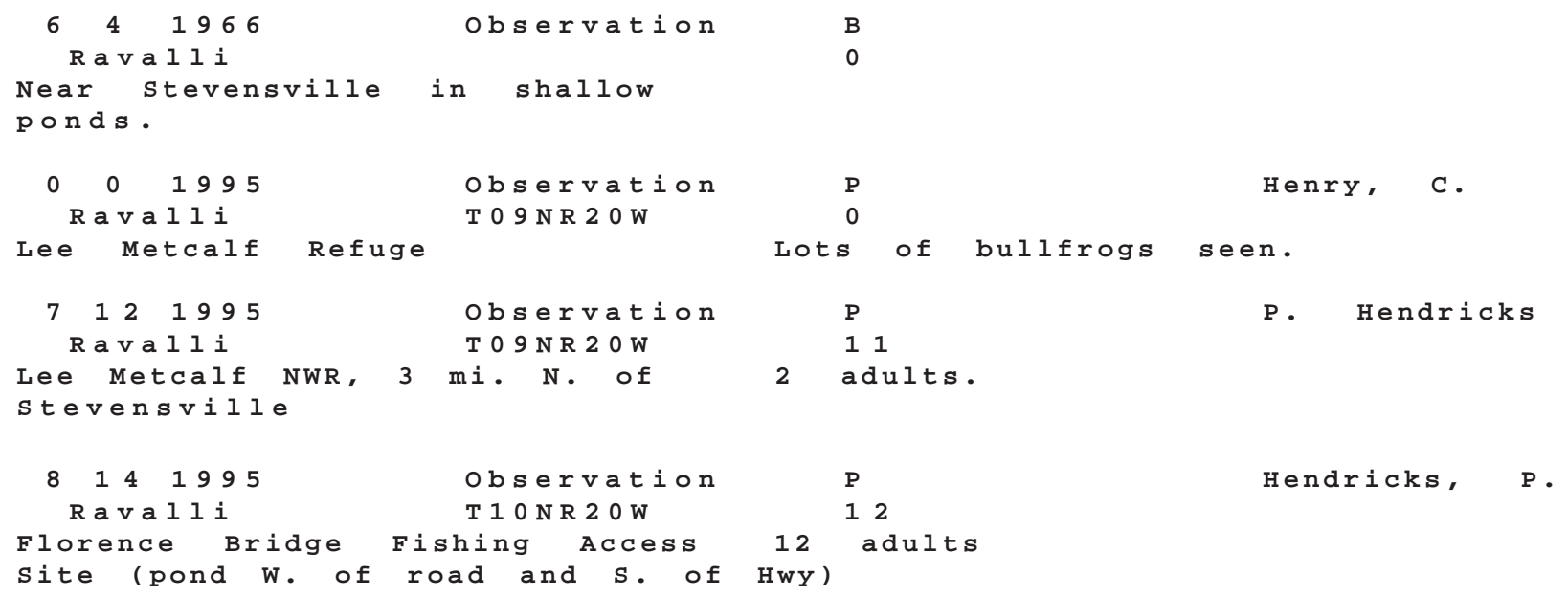

\section{RANA CATESBEIANA}


COUNTY LOCATION

\section{TOWNRANGE}

COMMENTS

BULLFROG RANA CATESBEIANA (cont.)

$\begin{array}{crl}8291996 & \text { MT960001 } \\ \text { Raval1i } & \text { T10NR20 } \\ \text { Florence } & \text { Bridge } & \text { Fishing Access } \\ \text { Site } & \end{array}$

observation

12
B Werner, $J$. S E

\section{RANA PRETIOSA}

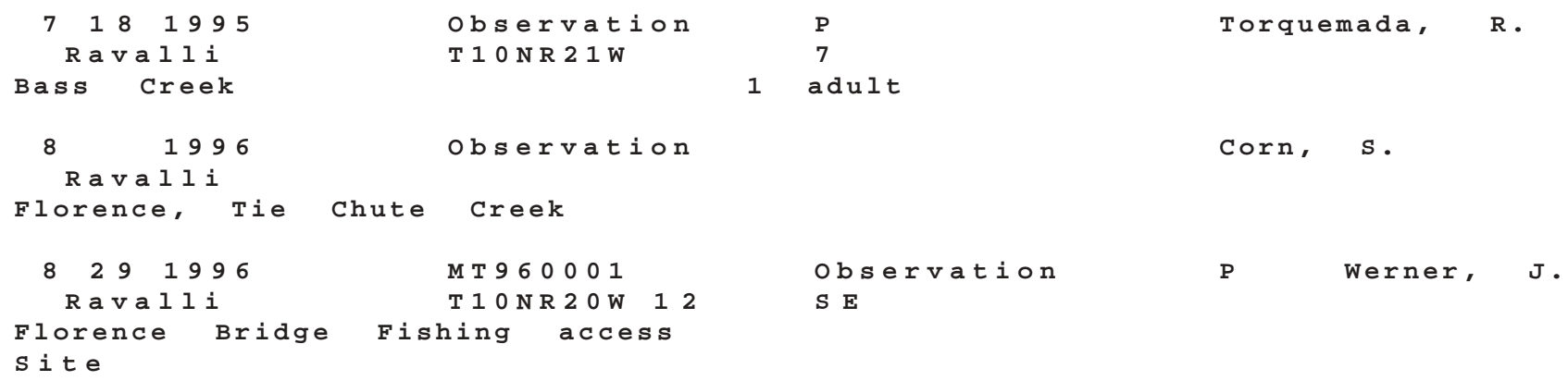

PAINTED TURTLE

CHRYSEMYS PICTA

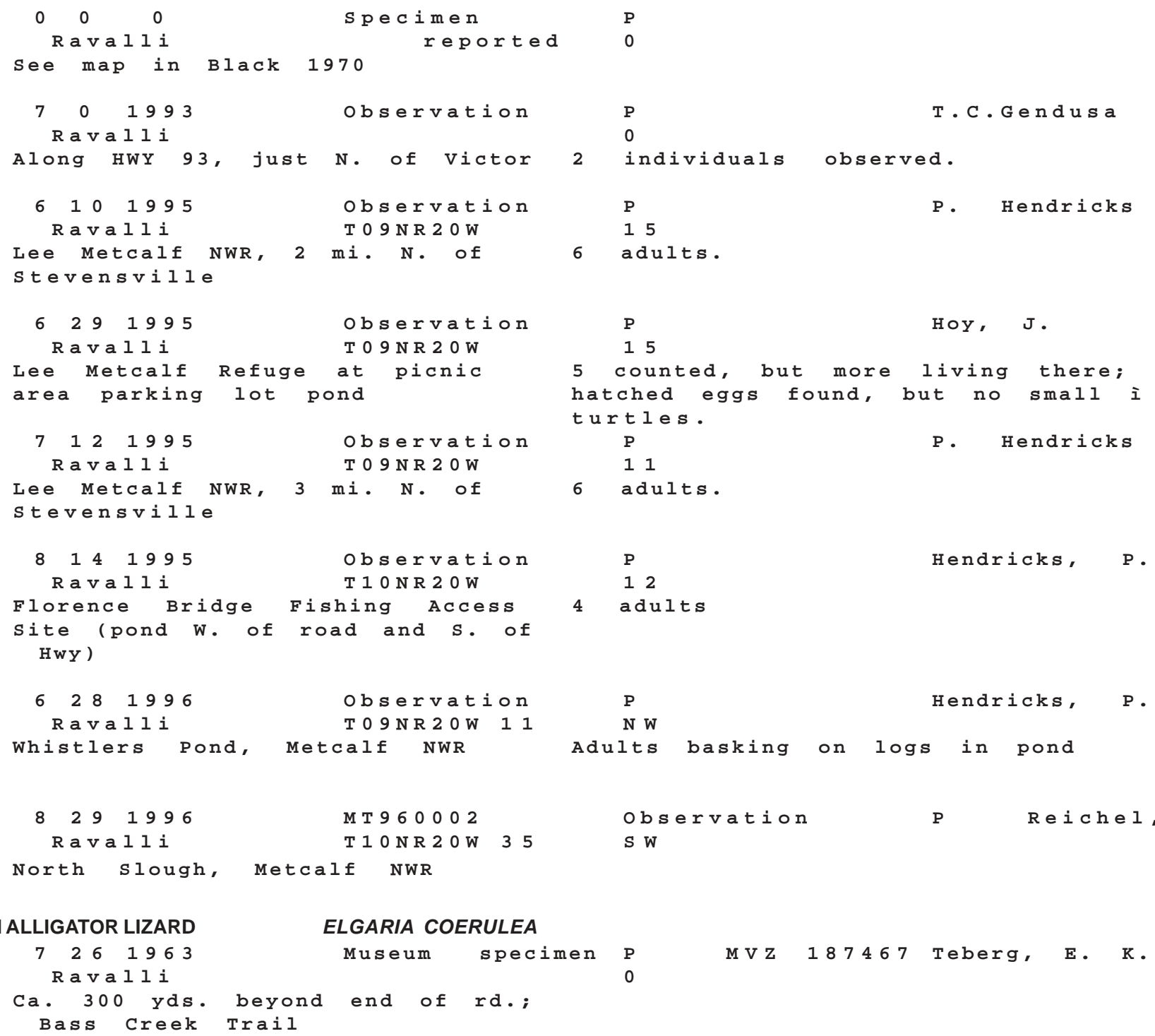

$\begin{array}{lllllll}7 & 2 & 6 & 1 & 9 & 6 & 3\end{array}$ $R$ a va $11 i$

Ca. 300 yds. beyond end of rd.;

Bass Creek Trail

\section{ELGARIA COERULEA}

$\begin{array}{llllllll}\text { Museum } & \text { specimen } & \text { P } & \text { MVz } & 187467 & \text { Teberg, } & \text { K. }\end{array}$

NORTHERN ALLIGATOR LIZARD 
COUNTY LOCATION

TOWNRANGE

\section{COMMENTS}

WESTERN SKINK

\section{EUMECES SKILTONIANUS}

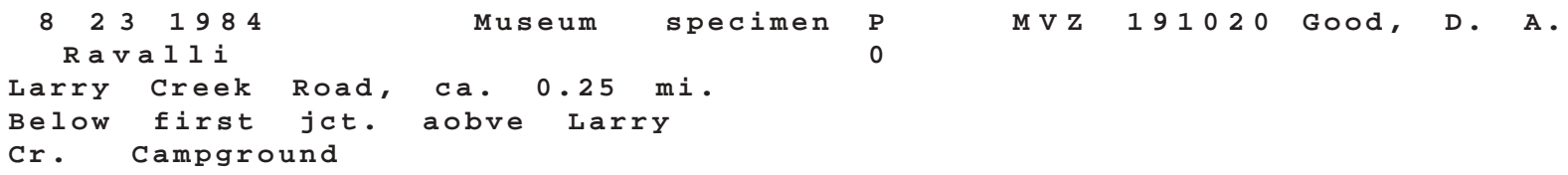

RUBBER BOA CHARINA BOTTAE

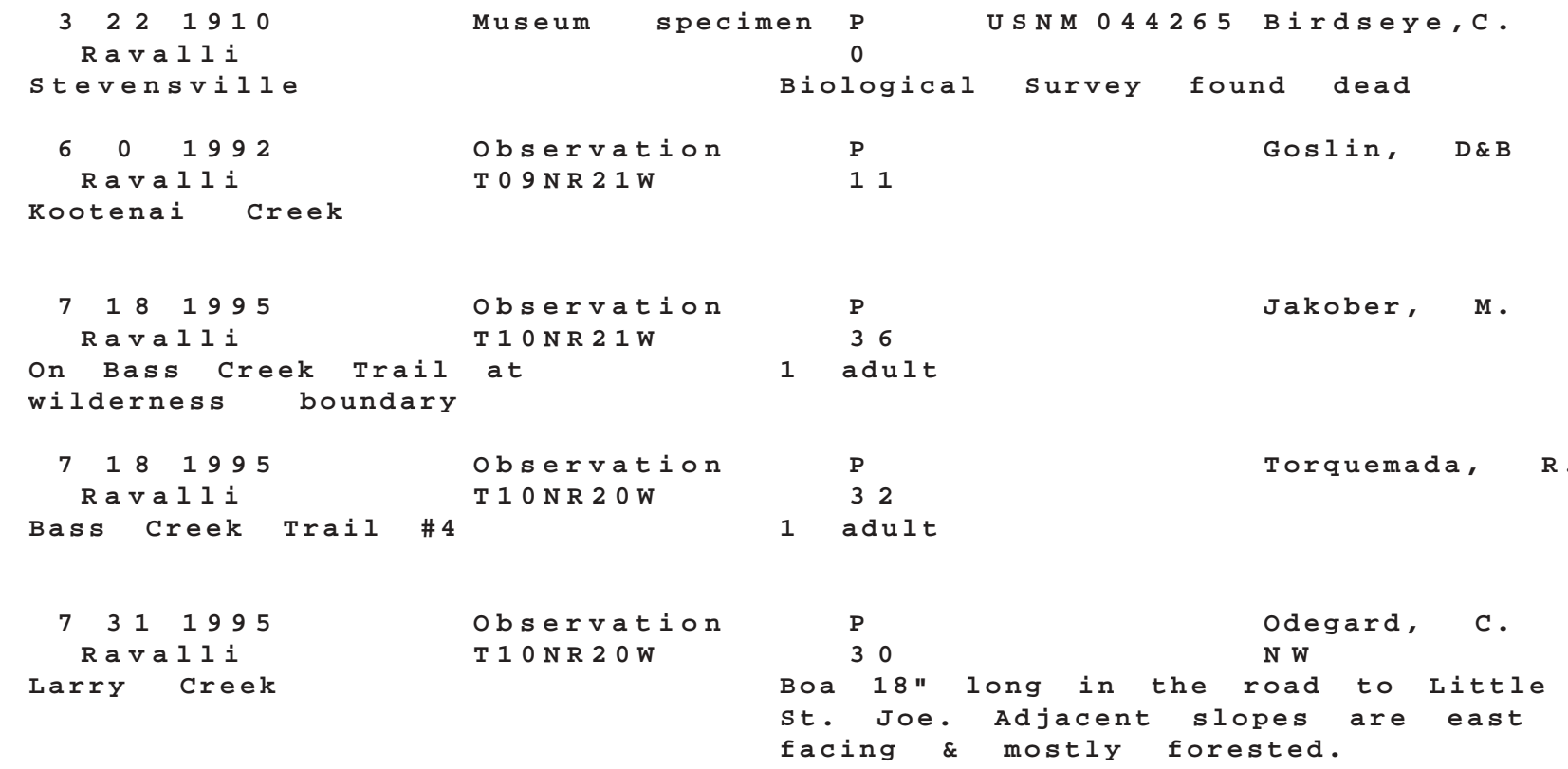

PINE OR GOPHER SNAKE

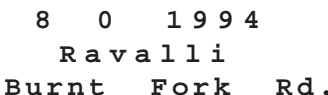

$0 \quad 0 \quad 1995$

Ravalli

Lee Metcalf Refuge

81111995

Ravalli

Hoy's yard

961995

Ravalli

Hoy's neighbor'

$925 \quad 1995$

Ravalli

Hoy's yard

PITUOPHIS CATENIFER

Observation T 08 NR $19 \mathrm{~W}$

observation T 09 N R 20 W

observation T 08 N R 20 W

Observation T 08 NR 20 W yard

Observation T 08 NR 20 W

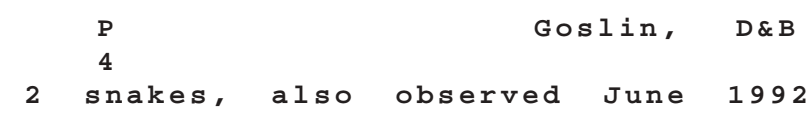

3

P

0

Henry, C.

3 snakes seen

P

13

H०Y, J .

P

14

Hoy, J .

P

13

.

WESTERN TERRESTRIAL

GARTER SNAKE

\section{THAMNOPHIS ELEGANS}

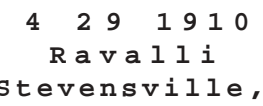
stevensville $3725 \mathrm{ft}$. $\begin{array}{rrr} & \text { Museum specimen } & \text { P } \\ \text { W Of, Bass Creek } & \end{array}$ 


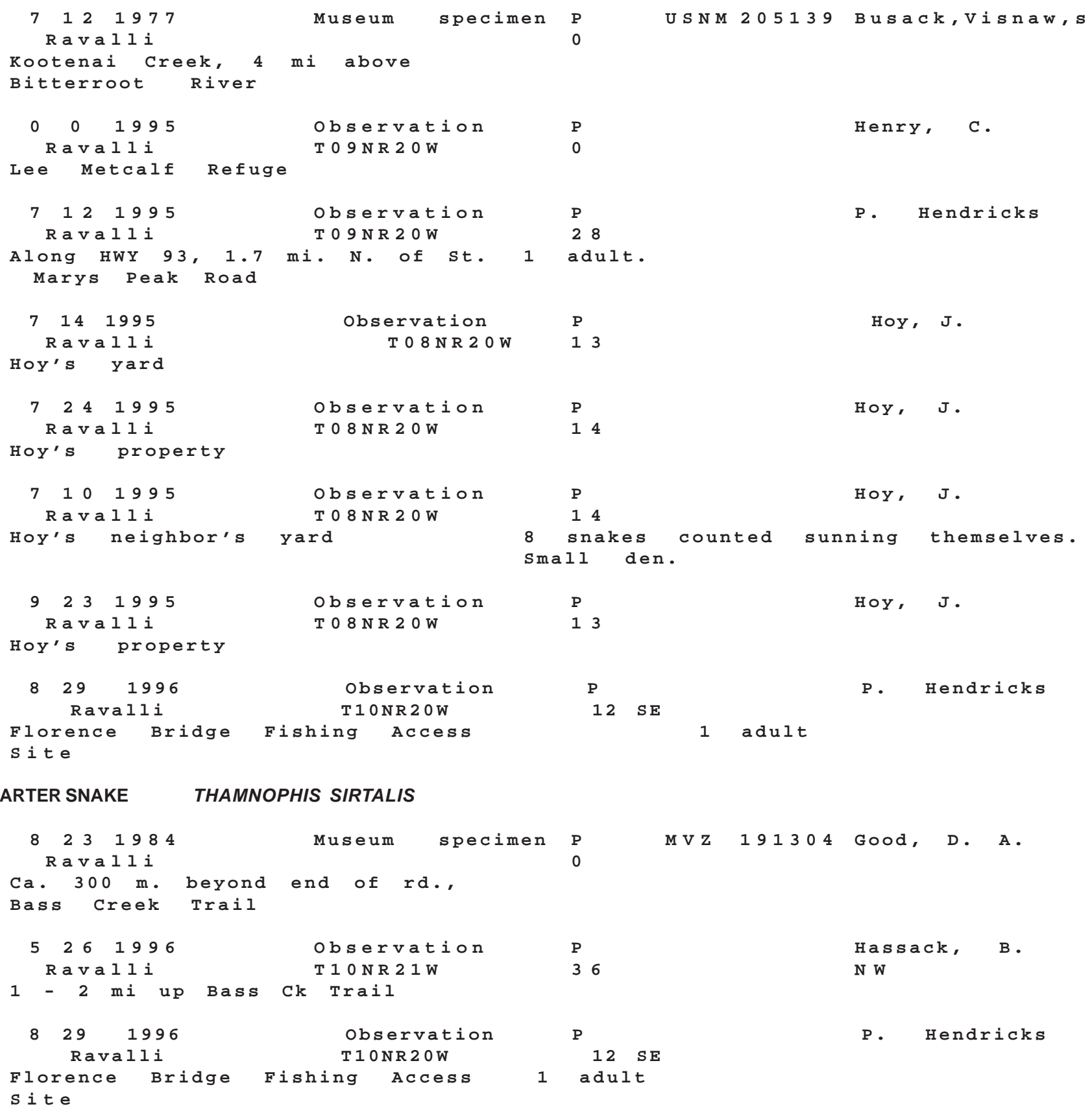

\section{THAMNOPHIS SIRTALIS}

\section{COMMON GARTER SNAKE}

